\title{
Challenges Faced by New Entrepreneurs and Suggestions How to Overcome Them
}

\author{
Eng Yi Fong ${ }^{1}$, Mohd Khata Bin Jabor ${ }^{1 *}$, Abdul Halim Zulkifli ${ }^{1}$, Mohamad Riduam Hashim ${ }^{1}$ \\ ${ }^{1}$ Faculty of Social Sciences and Humanities, Universiti Teknologi Malaysia, 81310 UTM Johor Bahru, \\ Johor. \\ *Corresponding Author Email: mkhata@utm.my
}

\begin{abstract}
All entrepreneurs especially the new entrepreneurs who are yet experienced in the business field, will have the tendency to face various challenges on their road to success in this field. Based on this, this paper sheds light on the various internal challenges as well as the external challenges that will be faced by the new entrepreneurs. Apart from that, this study also aims in identifying the possible suggestions that can be used to overcome those challenges. A review of secondary data including online journal articles and publications were used to gather the data for this study. From the study conducted, it was found that developing business idea and vision, raising capital for start-up and finding the right business location are the among common internal challenges faced by new entrepreneurs. As for the external challenges, new entrepreneurs are found to frequently face challenge in the form of competition, unforeseen business challenges and others. Besides that, the study's findings have also revealed several suggestions which can help to meet those challenges faced by entrepreneurs such as being optimistic towards the challenges faced, expanding the idea and vision to potential investors and so on.
\end{abstract}

Keywords: Mobile application, university students

\section{INTRODUCTION}

According to the Business Dictionary, entrepreneurship refers to the ability and willingness in organizing a business along with its potential risks in order to make a profit from it. According to Lowrey [1], the word 'entrepreneur' is being defined as an individual who desires to achieve his goals of economic survival and advancement. Applying to this context, entrepreneurs are the ones who will be involved in this business field and they are known as the people who organise and operate the businesses in the entrepreneurship world. In fact, they are the ones who are responsible in developing services and products in our everyday life. According to McKenzie et al. [2], entrepreneurs also holds the responsibility in improving consumer's lifestyles and also solving problems faced by consumers in this fast changing world besides contributing to the national economic income. However, all entrepreneurs especially the new entrepreneurs who are inexperienced in the business field, tend to face challenges on their road to success in this field. Various internal challenges as well as external challenges will be faced by the new entrepreneurs especially as they are still new in the business world and these act as hindrances to them in achieving success. Hence, in this paper, the various internal and external challenges faced by new entrepreneurs will be discussed in details. Also, useful suggestions to help in overcoming the challenges faced by them will be presented.

\section{METHODOLOGY/MATERIALS}

This study is done based on the secondary data or sources to discover the challenges faced by new entrepreneurs and also finding out the suggestions on how to meet them. These secondary data were collected by reviewing online journal articles and publications that were related to the topic of the study. In order to justify the research objectives, the data obtained were presented and discussed systematically.

\section{RESULTS AND FINDINGS}

The findings and discussions of the study on the various internal and external challenges faced by new entrepreneurs as well as the relevant suggestions for how to meet them is presented in this section.

\subsection{Internal Challenges Faced by New Entrepreneurs}

Entrepreneurs have to face numerous internal strains on the road to success in the business field. For a new entrepreneur, the internal challenges faced is commonly being referred to as the personal pressure experienced by an individual before starting off a new business. These internal challenges arose mostly from personal issues. Hence, this section will discuss the most common internal challenges faced by new entrepreneurs when starting up their own business. 


\subsubsection{Developing Business Idea and Vision}

Searching for business idea or creatively developing an idea is definitely a challenging task for new entrepreneurs as these ideas can hardly be found in their daily routine. In fact, it is the very first challenge faced by all entrepreneurs when they are to start a business from scratch. According to Lohitkumar et al. [3], in order to do so, an entrepreneur should be able to possess the ability to see what others cannot see or simply known as "envisioning the idea". When others see problems, an entrepreneur must be able to see opportunities instead. Only then, these opportunities will eventually turn out and forge into a business idea. In other words, an entrepreneur has to be able in bringing innovative products into existence by "creating value out of nothing" that is able to satisfy the public. Hence, the process of searching for a business idea is undeniably challenging where entrepreneurs have to possess this ability in transforming problems into business opportunities which is very difficult.

Besides that, developing a vision is another crucial aspect in starting up a business and definitely a business challenge as sometimes the entrepreneurs need to hold several duties that resembles the role of a sorcerer. It appears to be an internal challenge as developing a vision requires not only creativity but also the artistic sense from a new entrepreneur. For instance, as an entrepreneur, it is his or her duty to envision and forecast the future because it is vital for an entrepreneur to be ahead of his time before he loses his relevance [4]. Not only that, it is also said that an entrepreneur also holds the duty of bringing into present what is yet to be and also bringing solutions to people's problems. In other words, a new entrepreneur has to be observant in spotting problems faced by the public, coming out with a creative solution and then realising the visualisation. Three of these are in fact interrelated to each other in which not every individual may possess this ability. Hence, all of these are not easy to be done and challenging especially to new entrepreneurs who are green in this field.

\subsubsection{Raising Capital for Start-up}

According to Mkandawire [5], another challenge that new entrepreneurs usually face when starting a business after developing an idea is the challenge in raising capital for their business start-up. In fact, knowing only the core of a business idea is definitely not enough for a business to get started especially without business capital. Hence, an entrepreneur himself is responsible in searching for investors to raise the capital for his own business. It is one crucial step to be done and indeed a challenging task for new entrepreneurs.

According to Kanchana et al. [4], when building the first business, an entrepreneur not only have to convince the investors about something that does not exist, but also gain their trust in the task proposed so that they are willing to invest in it. In other words, raising capital is actually more than just simply asking for money. For investors, most of them prefer to invest in already established business that has minimal risk as they want to get returns for the risk they took. As for new entrepreneurs, it is difficult for them to be a competitor to these established businessmen as they are still new in the field and also gaining lower income in their business as compared to the established businesses. Hence, gaining investors' interest to invest in their non-established business is always difficult and undeniably a great challenge for them. This is why raising capital for business start-up can be categorized as one of the internal challenges faced by new entrepreneurs.

\subsubsection{Finding the Right Business Location}

Finding a good business location is a challenging task for an entrepreneur. As mentioned by Lohitkumar et al. [3], the location selected has to be an efficient location to ensure the future development of the business. In order to do so, an entrepreneur has to take into consideration the infrastructure, where clients are based with rapidly growing population, good road network and other amenities at a good place. This aspect can be considered as an internal challenge as a strategic place usually requires higher rental which in turns causes new entrepreneurs to face financial crisis. In contrast, a business place with a less strategic place will require lower rental, however they will be lower customer flow which results in lower income as to compared to a strategic one. Thus, dilemma happens. Hence, new entrepreneurs have to possess ability in searching for such strategic location to secure their business' development and it is undeniably a challenging task for them as good business locations are usually hard to be found and spotted. All these factors eventually contribute to the internal challenge among new entrepreneurs.

\subsection{External Challenges Faced by New Entrepreneurs}

Entrepreneurs have to face numerous external strains on the road to success in the business field. The external challenges mostly come from the environmental factors that evolve around a new entrepreneur. To be precise from a business perspective, external challenges refers to the market prices of a product, rules and regulations from government, the competition within the market and others. Hence, the most common external challenges faced by new entrepreneurs when starting up their own business will be discussed as follow.

\subsubsection{Dealing with Competition}

Competition is another obvious problem that all entrepreneurs will face when starting up a fresh business. Most of the new entrepreneurs view competition as a huge trouble as it makes their 
business to easily lose relevance in the eyes of their customers and eventually losing those customers. For instance, the increasing number of new businesses every day has brought upon competition to new entrepreneurs as their business ideas might clashes with those newly established businesses. Hence, causing them to face the risk of losing customers due to the customers' influence from other business choices.

Apart from that, as mentioned by Shahidi and Smagulova [6], usually the most common competition faced by new entrepreneurs is the ability in pursuing new business opportunities by keeping up with industrial changes and trends that are constantly evolving to attract customers. Trends have made and broken lots of businesses and thus poses a challenge especially for new entrepreneurs who are inexperienced in the business field. They are unlike the seasoned entrepreneurs who are used to swiftly adjusting their business to the current trend and use the trend to their advantages, in other words, spotting business opportunities [6].

However, in another point of view, competition can be said as a good challenge for an entrepreneur to develop their business. With the presence of competition, entrepreneurs will be forced to constantly improve their products or services to gain a stable position in the world market. Hence, it in fact stimulates innovation and the production of high quality products at great prices to attract customers to their businesses. Thus, competition can be said to be actually a more to positive challenge for new entrepreneurs where it indirectly trains them to learn and improve their business based on their innovation as well as creativity which are part of the crucial aspects of an entrepreneur [7]. However, dealing with competition is undeniably a challenging task especially for new entrepreneurs as they lack of experience in competing with other well-established entrepreneurs in the world.

\subsubsection{Unforeseen Business Challenges and Expenses}

As an entrepreneur, unforeseen business challenges and expenses can be said as one of the greatest challenge to be faced. This is because unexpected problems will strike without warning. Thus, an entrepreneur must be always prepared for whatever that comes to them and solve the challenges or crisis faced. In fact, these unforeseen business challenges come in many forms, for example like unexpected law suits, inconsistent government policy, bad debts from customers, inadequate stock or even unpaid bills and taxes [8]. One of the significant example is the Asian Financial Crisis that happened in the year 1997. It has caused a great impact on the businesses in Asian countries where most of the established businesses have been closed down due to the unstable and unexpected economical blow. All these unforeseen or unexpected business challenges have to be handled properly by entrepreneurs or else it might affect the progress in building a successful business.

According to Kanchana et al. [4], an entrepreneur needs to face the challenge in handling unforeseen business expenses that are unknowingly increasing as it might result in constant negative cash flow if not tackled properly and finally leading to business failure. Hence, all these aspects obviously pose as an external challenge for new entrepreneurs as they might not be capable enough in handling these unexpected storms in the business field.

\subsubsection{Finding Good Customers}

The other external challenge that new entrepreneurs will face in starting a business is finding good customers. Finding good customers is a challenging task and it is in fact necessary in contributing to the success of a certain business. Good customers can help to build a business where they will always try to do the right thing that can benefit both the company and themselves [3]. Besides that, they will always appear loyal to the company besides being very forgiving if there is a mistake or apology made by a certain business. Furthermore, they will also provide constructive comments on the service of a certain new business so that improvements can be made to it by the entrepreneurs. However, good customers like this are not many to be found.

Instead, bad customers are more commonly to be seen and new entrepreneurs must beware of them. Bad customers are commonly being categorized as those people who are very picky and bossy on minor issues that happens. Bad customers will always try to ruin the business where they will exploit the company by looking for loopholes in the company's policy and try to tear the company apart [4]. Hence, as a new entrepreneur who is yet experienced, he must be prepared to face good and bad customers in the process of developing a certain business. However, good customers are rarely to be found and thus making the task of finding good customers that helps in building their business to be a difficult and challenging task especially for a new entrepreneur.

\subsection{Suggestions to Meet the Challenges}

Despite both the external as well as the internal challenges that new entrepreneurs have to face in the fast changing world, there are several ways that entrepreneurs can practice in order to overcome the challenges faced by them. The suggestions to meet those challenges faced by new entrepreneurs will be discussed as below. 


\subsubsection{Being Optimistic Towards Challenges Faced}

Challenges, obstacles and setbacks are the common hindrances that new entrepreneurs always face while trying to establish new opportunities in the business field. Starting from the start-up of an idea until the real formation of a business, entrepreneurs will experience challenges both internally and externally as discussed above. New entrepreneurs tend to face these hurdles with negative attitudes such as giving up easily and feeling stressful in which these attitudes could obstruct not only the market flow of their business but also the competitive spirit among entrepreneurs in the same business field [9]. Thus, instead of having those negative attitudes, new entrepreneurs should regard these challenges as opportunities for them to improve upon a certain existing weakness as well as taking some measures in order to avoid experiencing the same failure again in future [10]. Apart from that, Voogd [11] also stated that a successful entrepreneur will always view failure optimistically which makes them successful in their career. In other words, they are to be optimistic in every situation, either good or bad, in order to achieve success. Besides that, new entrepreneurs are also advised to seek for motivation in overcoming the challenges faced, mostly from their initial intention in starting up the business [12]. It is suggested that instead of taking challenges as hindrance, entrepreneurs should instead grab the opportunities to establish a business venture and take actions related to its success.

\subsubsection{Expand the Idea and Vision to Potential Investors}

One of the internal challenges faced by new entrepreneurs is raising capital for their business startup. Also, entrepreneurs face problem in developing others' visualization towards their business prospective as people might fail to imagine what is being described by them. Hence, in order to face this challenge, it is suggested that an entrepreneur should develop the ability or skills to sell their idea and vision to the potential investors. According to Fand and Kohan [13], potential investors are those who tend to seek for the quality of your management team, strength of your business opportunity as well as the return that they will get upon their investment on your business field. Hence, as new entrepreneurs, it is very important for them to identify the potential investors who can help them in developing their business so as to obtain greater chances in finding an investor who is willing to invest in their business.

Meanwhile, new entrepreneurs should also empower themselves with the ability in convincing the investors to put their trust towards them by investing in their proposed business idea. That is why it is advisable for new entrepreneurs to have a clear and organisable business plan which can attract the attention of their potential investor as well as their interest towards the proposed business idea. Besides that, a business plan also can help the entrepreneurs to be more realistic in planning as well as taking appropriate actions or decisions while developing their business [14].

\subsubsection{Research the Target Market and Analyse Competitive Products}

Another external challenge that is commonly faced by entrepreneurs is competition, either with newly startup or established businesses. In order to tackle this problem, it is suggested that new entrepreneurs should do some research on the target market as well as analysing the competitive products that exist in the market. According to Holland [15], he stated that in order to survive in the competitive business field, it is suggested that entrepreneurs should analyse competitors' successful selling methods, pricing and advertising strategies to help them in dealing with the competition faced. With these unique winning strategies that they own, it will definitely help them to outweigh the other businesses despite those competitions they face [16].

On the other hand, it is also suggested for entrepreneurs to do research on the required aspects on their business through online as it is free of charge and most importantly, it can show the recent trend of the requirements in the business market. It is highly recommendable because social media is easily accessible by the public nowadays. Besides that, staying online has become a daily routine for most people, hence, enabling entrepreneurs to gain information more easily. For example, people nowadays will have the habit of leaving comments on a certain product or stating the daily problems they faced on the internet. Thus, entrepreneurs can make use of these information and strategize their business idea in order to attract customers. Also, Haenlein [17] suggested that through social media, it enables users to research on the products as well as the service in a more efficient and convenient way.

\subsubsection{Enrich Oneself by Reading Inspiring Materials}

Being a new entrepreneur who is about to start a business is not easy as they will face both internal and external tensions such as mood swings, lack of skilled labours and others. Thus, it is recommended for them to bring in positive thoughts for their own good. Reading materials like articles or biography related to a successful businessman will be useful in helping entrepreneurs to overcome their negative mind set upon the setbacks that they faced in the business field [18]. "Business Adventures" by John Brooks which highlights the reasons behind those success and failure of businesses is one of the famous reading material that is being recommended to new entrepreneurs. Apart from that, it is suggested that new entrepreneurs may also do other readings in order to enrich themselves with useful knowledge that can help them in facing the challenges and also developing their businesses [19]. 


\section{CONCLUSION}

An entrepreneur can be defined as a person who always seeks for changes, responds to it and exploits it as an opportunity as well as constantly pursuing their goals even there are various hindrance and obstacles (Drucker, 2005). As mentioned earlier, entrepreneurs are also responsible in contributing to the economic growth in our country. However, new entrepreneurs who are yet experience in the business field especially are prone to face challenges on their road to success. From the findings, it was found that the common internal challenges faced by new entrepreneurs include developing business idea and vision, raising capital for start-up and finding the right business location. Meanwhile, for external challenges, entrepreneurs have to face challenges such as competition, unforeseen business challenges and expenses as well as finding good customers. Thus, in order to overcome the challenges, some suggestions have been included in this paper as discussed previously.

\section{REFERENCES}

[1] Lowrey, Y. L. (2003). The Entrepreneur and Entrepreneurship: A Neoclassical Approach. Business Administration for the ASSA Annual Meetings.

[2] McKenzie, B., Ugbah, S. D., and Smothers, N. (2007). "Who is an Entrepreneur?" Is It Still the Wrong Question? Academy of Entrepreneurship Journal. 13(1), 23-43.

[3] Lohitkumar, K., Sivaprasad, A. and Reddy, C. S. (2016). Challenges Faced by New Entreprenuers. $3^{\text {rd }}$ International Conference on Recent Innovations in Science Engineering and Management. 997-1001.

[4] Kanchana, R.S., Divya, J. V. and Beegom, A. A (2013). Challenges Faced by New Entrepreneurs. International Journal of Current Research and Academic Review. 1(3), 71-78.

[5] Nyanga, T. (2013). Challenges Faced by Young Entrepreneurs at Mandava Market in Zvishavane, Zimbabwe. International Journal of Science and Technology. 2(2), 113-117.

[6] Shahidi, M. and Smagulova, A. (2008). The Challenges of Entrepreneurship in Dynamic Society. Central Asia Business. 1(1), 34-45.

[7] Kaburi, S. N., Mobegi, V. O., Kombo, A., Omari, A. and Sewe, T. (2012). Entrepreneurship Challenges in Developing Economies: A Case of Kenyan
Economy. International Journal of Arts and Commerce. 1(4), 264-274.

[8] Moutry, C. (2009). Looking Ahead: Opportunities and Challenges for Entrepreneurship and Small Business Owners. Western New England Law Review. 31, 763-780.

[9] Escalante, C. L., and Turvey, C. G. (2006). Innovation and Entrepreneurship in Rural Communities: Early Business Survival Challenges for the Agribusiness Entrepreneur. Southern Agricultural Economics Association Annual Meetings, 1-27.

[10] Kuratko, D. and Hodgetts, R. (2007). Entrepreneurship: Theory, Process, Practice. Mason, Ohio: Thomson South-Western, Cop.

[11] Voogd, P. (2015). The Entrepreneur's Blueprint to Massive Success: Creating an Exceptional Lifestyle While Doing Business on Your Terms.

[12] Segal, G., Borgia, D., and Schoenfeld, J. (2005). The Motivation to Become an Entrepreneur. International Journal of Entrepreneurial Behavior and Research. 11(1), 42-57.

[13] Fand, E. and Kohan, S. (2013). Chapter 4: Writing A Business Plan. School of Management.

[14] Swanson, J. and Baird, M. (2003). Engineering Your Start-Up, a Guide for the High-Tech Entrepreneur. Professional Publications, Inc.

[15] Drucker, P. (2005). Innovation and Entrepreneurship: Practice and Principles. Butterworth-Heinemann. Repr

[16] Gretzel, U., Fesenmaier, D. R., Formica, S., and O'Leary, J. T. (2006). Searching for the Future: Challenges Faced by Destination Marketing Organizations. Journal of Travel Research. 45(2), 116126.

[17] Haenlein, M. (2010). Users of the World, Unite! The Challenges and Opportunities of Social Media.

[18] Khosla,R. and Beena, F. (2015). Leading Entrepreneurs in India: Startup Business Journey and the Challenges. Advances in Economics and Business Management.

[19] Sandberg, W. R., and Hofer, C. W. (1987). Improving New Venture Performance: The Role of Strategy, Industry Structure, and the Entrepreneur. Journal of Business Venturing. 2(1), 528. 